\title{
Mutual Funds and Their Advisers: Strengthening Disclosure and Shareholder Control
}

The close relationship between a mutual fund and its management company has long generated fears concerning the size of fees paid to the management company for investment advice. ${ }^{1}$ The original regulatory approach relied upon disclosure and a degree of shareholder participation in the fund's decisionmaking process. ${ }^{2}$ The Securities and Exchange Commission (SEC) and Congress reacted to subsequent undesirable fee arrangements in management contracts by changing the regulatory strategy altogether. Congress established a standardized fee structure ${ }^{3}$ and placed upon courts the task of supervising fees. ${ }^{4}$ These changes, made in 1970, have serious shortcomings and were undertaken prematurely. A system of shareholder control and meaningful disclosure had not been fully developed, and the shift in strategy was unwarranted.

\section{Regulation of Mutual Fund Advisory Fees}

A mutual fund ${ }^{5}$ is usually organized by persons or corporations which are interested in providing it with management and research services. ${ }^{6}$ The fund, while under the control of the incorporators and original shareholders, enters into management and research agreements with these same persons. Once the fund undertakes to offer its

1. Note, The Mutual Fund and Its Management Company: An Analysis of Business Incest, 7I YALE L.J. 137 (1961).

2. See p. 1476 infra.

3. Investment Advisers Act $\$ 205,15$ U.S.C. $\$ 80 \mathrm{~b}-5$ (1970) [hereinafter cited as $\S 205$ ].

4. Investment Company Act $\S 36(\mathrm{~b}), 15$ U.S.C. $\$ 80 \mathrm{a}-35(\mathrm{~b})$ (1970) [hereinafter cited as $\$ 36(\mathrm{~b})]$.

5. Mutual funds are publicly held corporations which engage only in such activity as is necessary to the distribution of their own shares and the management of their portfolio. Although not an essential characteristic, almost all funds are diversified. SEC, Report on the Public Policy Implications of INVESTMENT Company Growth, H.R. ReP. No. 2337, 89th Cong., 2d Sess. 44 (1966) [hereinafter cited as PPI]. Diversification is defined to mean that 75 percent of the company's assets are invested in cash and sccurities, that no greater than 5 percent of the fund's assets are invested in the securities of one issuer, and that the company owns no more than 10 percent of the outstanding voting stock of one issuer. Investment Company Act, 15 U.S.C. $\$ 80 \mathrm{a}-5(\mathrm{~b})(\mathrm{I})(1970)$. Open-ended mutual funds have outstanding redeemable shares, id. $\$ 80 \mathrm{a}-5(\mathrm{a})(\mathrm{1})$, and engage in a continuous offering of their shares at a price determined by the size of their portfolio and the number of shares outstanding. 17 C.F.R. $\$ 270.22 c-1$ (a) (1973). For a definition of net assets for these purposes, see SEC Investment Company Act Release No. 5569 (Jan. 10, 1969).

6. This process is explained in detail in Lobell, The Mutual Fund: A Structural Analysis, 47 VA. L. REv. 181 (1961). 
shares publicly, it becomes subject to the regulatory requirements of the Investment Company Act. ${ }^{7}$ The fund and its adviser must also comply with the regulatory provisions of the Securities Act of 1933, ${ }^{8}$ the Securities Exchange Act, ${ }^{9}$ and the Investment Advisers Act. ${ }^{10}$

\section{A. Pre-1970 Regulatory Scheme}

Prior to the 1970 Amendments $^{11}$ to the Investment Company Act and the Investment Advisers Act, regulation of fees paid to the companies providing advisory and management services for a fund took two forms. One type of regulation sought to maintain shareholder control over the awarding by the fund of these management and advisory contracts. The Investment Advisers Act requires stockholder approval of new contracts with an investment adviser and approval of renewals of advisory contracts by a majority of the noninterested directors or a majority of the stockholders. ${ }^{12}$ The Act also requires stockholder election of all the directors over a five year period. ${ }^{13}$

The second type of pre-1970 regulation of mutual funds involved disclosure requirements. These attempted to enhance competition among fund managers by providing information to shareholders and potential shareholders about the benefits of the fund received in return for the advisory and management fees paid. Disclosure was tied as well to shareholder participation in the corporate decisionmaking process. An enlightened and rational vote requires information about the advisory contracts and the quantity and quality of services provided to the fund. ${ }^{14}$

7. 15 U.S.C. $\$ \$ 80 \mathrm{a}-1$ to $-52(1970)$.

8. Id. $\$ \$ 77 \mathrm{a}-77 \mathrm{bbbb}$.

9. $I d . \$ \$ 78 \mathrm{a}-78 \mathrm{hh}-1$.

10. Id. $\$ \$ 80 \mathrm{a}-1$ to -52 .

11. Act of Dec. 14, 1970, Pub. L. No. 91-547, 84 Stat. 1413. For the complete statutes with amendments, see notes $3-4$ supra.

12. For new contracts, see 15 U.S.C. $\$ 80 \mathrm{a}-15$ (a) (1970). For renewal of contracts, see id. \$\$ 80a-15(a)(2) \& -15(c). The Investment Company Act also requires that at least 40 percent of the fund's board consist of noninterested directors, id. $\$ 80 \mathrm{a}-10(\mathrm{a})$. "Interested person" as defined in $\S 2(\mathrm{a})(19)$, id. $\$ 80 \mathrm{a}-2(\mathrm{a})(19)$, includes, among others, affiliated persons, family members of such persons, and those persons having a material business relationship in the last two years with the company, the principal underwriter, or the principal executive officers of the company. 15 U.S.C. $\$ 80 \mathrm{a}-10$ (b) contains a more complex set of rules limiting the number of fund directors who are brokers or persons affiliated with brokers for the fund; underwriters or interested persons of the principal underwriters for the fund; or affiliated persons of any investment bankers when any such persons serve as either directors, officers, or employees of the fund. 15 U.S.C. $\$ 80 \mathrm{a}-10$ (c) limits the number of directors of a fund who are officers, directors, or employees of one bank. 15 U.S.C. $\$ 80 \mathrm{a}-10$ (d) exempts certain no-load companies from $\$ 10(a)$ and $\S 10(b)(2)$ except that there must be at least one noninterested director.

13. Id. $\$ 80 \mathrm{a}-16(\mathrm{a})$.

14. Cf. Schotland, Changes in Disclosure, Bus. LAw., Mar. 1974, at 31, 39 (special issue). 
While the pre-1970 regulatory scheme was in effect, the SEC noticed what it considered undesirable industry fee patterns: Investment advisory fees were generally calculated as a fixed percentage of asset size even though there were significant economies of scale to management and provision of advice. ${ }^{15}$ Investors were not reaping the rewards of these lowered costs of management of large portfolios. ${ }^{16}$

Congress was also convinced that certain performance fee arrangements were encouraging excessive risk taking and inflated fees. ${ }^{17}$ These arrangements rewarded the advisory company with a fee bonus when the performance of the portfolio of the fund company exceeded a sometimes irrelevant index and often provided no penalty for performance of the fund portfolio below the chosen index. ${ }^{18}$ Indexes for comparison could be selected which would provide rewards when the fund's value increased with a general market rise although such increases in portfolio value might have no relationship to the advising capabilities of the fund's advisory company.

\section{B. The 1970 Amendments}

The major congressional responses ${ }^{19}$ to the SEC's petition for change were the addition of $\S 36(\mathrm{~b})$ to the Investment Company Act $^{20}$ and the amendment of $\S 205$ of the Investment Advisers Act. ${ }^{21}$ These two provisions approach the problem of excessive fees in two different ways: Section $36(\mathrm{~b})$ embodies a new fiduciary duty concept; section 205 establishes a performance fee structure. Neither assures an arm's length advisory fee.

\section{Section $36(b)$}

Section 36(b) of the Investment Company Act imposes a fiduciary duty $^{22}$ on investment advisers and their affiliates with respect to fees

15. See PPI, supra note 5 , at $11,102$.

16. S. Rep. No. 184, 9lst Cong., lst Sess. 6 (1969) [hereinafter cited as S. REP. No. 184].

17. Id. at 45; SEC, INSTItutional Investor Study Report, H.R. Doc. No. 64, 92d Cong., Ist Sess. 25 (1971) [hereinafter cited as ISR].

18. For a detailed description of these arrangements, see ISR, supra note 17, at 254-66.

19. A minor change, $\$ 15$ (c) of the Investment Company Act, 15 U.S.C. $\$ 80 a-15(c)$ (1970), provides that the directors of a registered company shall have the duty to request and evaluate, and the adviser to the company the duty to furnish, information necessary to evaluate the advisory contract. This provision does not appear to limit the terms of an advisory contract. See S. REP. No. 184, supra note 16, at 7 . It may, however, give shareholders judicially enforceable rights against directors who fail to evaluate the advisory contract; of. Brown v. Bullock, 294 F.2d 415, 420 (2d Cir. 1961); Propp v. Sadacca, 40 Del. Ch. 113,175 A.2d 33 (1961).

20. 15 U.S.C. $\$ 80$ a-35(b) (1970).

21. Id. $\$ 80 \mathrm{~b}-5$.

22. An interesting attempt to define this duty has been made in Note, Mutual Fund Advisory Fees and the New Standard of Fiduciary Duty-Interpreting the 1970 Mrutual Fund Act, 56 CoRnell L. REv. 627 (1971). 
received from an investment company registered under the Investment Company Act, or from its security holders. For breach of this duty a lawsuit may be brought by a shareholder on behalf of the company against the person accepting such fees. ${ }^{23}$ Misconduct of the defendant need not be proved in order to establish a breach of duty. ${ }^{24}$ The thrust of the provision is, thus, to regulate fees, not misconduct.

'Section 36(b) embodies a more stringent standard than that employed by most state courts. In its report to Congress, the SEG, after a review of relevant cases, ${ }^{25}$ concluded that the state courts did not take into account the domination of mutual funds by advisory companies in suits alleging that unreasonably high fees were paid by the satellite mutual funds to their investment advisers. ${ }^{26}$ The SEC's solution to this problem would have required that fees paid to an investment adviser of an investment company be reasonable. ${ }^{27}$

Although Congress did not adopt the SEC's suggested reasonableness standard, ${ }^{28}$ it clearly disapproved of the review that advisory fees had received in state courts, under which relief was premised on a showing of "shocking" deviation from industry standards. ${ }^{29}$ What constitutes a breach of fiduciary duty under this section is, however, enigmatic. One possible interpretation ${ }^{30}$ is that there is a range of per-

23. 15 U.S.C. $\$ 80 \mathrm{a}-35(\mathrm{~b})(1970)$.

24. Id. $\$ 80 \mathrm{a}-35(\mathrm{~b})(\mathrm{l})$.

25. PPI, supra note 5, at 133-38 (reviewing Acampora v. Birkland, 220 F. Supp. 527 (D. Colo. 1963); Saxe v. Brady, 40 Del. Ch. 474, 184 A.2d 602 (1962); Meiselman v. Eberstadt, 39 Del. Ch, 563, 170 A.2d 720 (1961).

26. PPI, supra note 5, at 141. For description of this domination, see id. at 145 . See also Note, supra note 1 .

27. PPI, supra note 5, at 143-47.

28. The evolution of $\S 36(\mathrm{~b})$ is described in Note, supra note 22 , at 629-30. See also S. REP. No. 184, supra note 16 , at 5 . Congress rejected many of the factors which the SEC had suggested as considerations relevant to the reasonableness of an investment management fee. For example, the SEC suggested comparison with "comparable" fees of nonfund managers, e.g., bank trust departments. PPI, supra note 5, at 144. Section 36(b) does not provide for this. Fund industry practice is the relevant guide. S. REP. No. 184, supra note 16, at 6 . Congress also codified the notion from case law that shareholder and unaffiliated director ratification are factors in determining whether the fiduciary obligation of the advisory company had been fulfilled. $\$ 36(b)(2)$. The SEC would have omitted this consideration. PPI, supra note 5 , at 144 .

29. In Saxe v. Brady, 40 Del. Ch. 474, 486, 184 A.2d 602, 610-11 (1962), the court determined the reasonableness of the fee paid by asking whether there was a shocking disparity between the fee paid by the fund to the advisory company in question and the fee paid to the average similarly situated advisory company.

The "shocking" criterion was explained in Acampora v. Birkland, 220 F. Supp. 527, 549 (D. Colo. 1963), where the court concluded that comparison of fees to industry averages is only evidentiary; exceeding such average is not conclusive of the legal excessiveness of fees, unless such fees exceed the average by a shocking amount.

30. Barriers to federal actions under $\S 37$ of the Investment Company Act, 15 U.S.C. $\$ 80 \mathrm{a}-36(1970)$, were apparently a partial motivation behind the enactment of $\S 36(\mathrm{~b})$. See S. REP. No. 184, supra note 16, at 5. Section 37, which provides a cause of action to a fund shareholder against a person who steals, unlawfully abstracts, converts or embezzles from a registered investment company, was interpreted at one time to cover an allegation of a payment by a fund of excessive fees to an investment. 
missible fees, encompassing lesser deviations from industry standards than those permissible under the "shocking" test of state law. ${ }^{31}$ The Senate report stated that, with respect to reducing fees to reflect economies of size, "best industry practice will provide a guide." 32 This test is not likely to approximate closely an arm's length fee, in view of the complete absence of arm's length bargaining in the industry. ${ }^{33}$ Without such an arm's length standard, reviewing courts would establish fees for the entire industry and in effect engage in the nonjudicial function of ratemaking. ${ }^{34}$ These courts would have no legislative guide in making important policy trade-offs incident to the process of setting rates for the industry as a whole. ${ }^{35}$

\section{Section 205}

In 1970 Congress brought investment company advisers under the Investment Advisers $\mathrm{Act}^{36}$ and simultaneously amended $\S 205$ to exempt these advisers from the Act's general prohibition against fees based on performance. In order for an adviser of a fund to receive extra compensation pursuant to a contractual schedule based on "per-

adviser. Brown v. Bullock, 294 F.2d 415 (2d Cir. 1961). The Eighth Circuit, however, reasoned that federal courts were not intended to review corporate relationships under the Investment Company Act. Brouk v. Managed Funds, Inc., 286 F.2d 901 (8th Cir. 1961).

31. The SEC had interpreted the cases to mean that shareholder ratification precluded effective judicial inquiry into the reasonableness or fairness of advisory fees. PPI, supra note 5, at 136. Both the Senate and the House reports accompanying new $\$ 36(b)$ also concluded that, under state law, the existence of a breach of fiduciary duty required that fees paid " 'shock the conscience of the court." $S$. REP. No. 184, supra note 16, at 5; H.R. REP. No. 1382, 91st Cong., 2d Sess. 7 (1970).

The SEC was correct in concluding that state courts would not upset fees unless they were wasteful or unconscionable, meaning that "no person of ordinary sound business judgment would be expected to entertain the view that the consideration was a fair exchange for the value which was given," Saxe v. Brady, 40 Del. Ch. 474, 486, 184 A.2d 602, 610 (1962). But it is inaccurate to say that state courts did not inquire at all into the reasonableness of fees. For example, in Saxe the court found that the fees paid were reasonable and that they bore a reasonable relationship to expenses. Id. In Meiselman v. Eberstadt, 39 Del. Ch. 563, 564, 170 A.2d 720, 721 (1961), the court defined the real issue as the reasonableness of compensation. In Acampora v. Birkland, 220 F. Supp. 527, 549 (D. Colo. 1963), the court concluded that the issue was whether the fees are unreasonably high.

32. S. REP. No. 184, supra note 16 , at 6 .

33. One court suggested the arm's length test, but did not venture to say how it should be applied. Galfand v. Chestnutt, [1973 Transfer Binder] CCH FED. SEC. L. REP. If 94,218 (E.D. Pa. 1973).

34. See United States v. Socony-Vacuum Oil Co., 310 U.S. 150 (1940); United States v. Trenton Potteries Co., 273 U.S. 392 (1927); Saxe v. Brady, 40 Del. Ch. 474, 487, 184 A.2d 602, 610 (1962). Courts generally refuse to interfere with rate making unless it passes the threshold of confiscation. St. Joseph Stock Yards Co. v. United States, 298 U.S. 38, 53 (1935); Lindheimer v. Illinois Tel. Co., 292 U.S. 151, 164 (1934).

35. Although $\$ 36(\mathrm{~b})$ was not intended to involve the courts in rate regulation, the legislative history indicates that Congress found that investment advisory fees for the industry as a whole were unreasonably high. S. REP. No. 184, supra note 16, at 5, 6. See also Sterrett, Reward for Mutual Fund Sponsor Entrepreneurial Risk, 58 CORNELL L. Rev. 195, 208 (1973).

36. Act of Dec. 14, 1970, Pub. L. No. 91-547, § 24, 84 Stat. 1430. 
formance," $\$ 205$ requires that the return on the fund's portfolio be greater than the return on an "appropriate" index of securities prices or such other measure of investment performance as the SEC may specify. ${ }^{3 \pi}$

In determining whether an index is appropriate for a particular investment company, directors of the fund are required by the SEC to consider such general factors as volatility, diversification of holdings, types of securities owned, and objectives of the investment company. ${ }^{38}$ For an investment company that is widely diversified, a broadly based index of common stocks, weighted by market value, would ordinarily be appropriate, though the SEC indicates an index based upon a relatively few large "blue chip" stocks would not. ${ }^{30}$ For investment companies that invest exclusively in a particular "type" of security, a specialized index, or a broadly based, market-value-weighted index would be appropriate..$^{40}$

The SEC comparison standard is thus an index in which risk adjustment is considered only qualitatively in terms of the composition of the index. ${ }^{41}$ This approach is theoretically erroneous. Capital market theory makes clear the necessity of measuring performance in two dimensions-return and risk. ${ }^{42}$ Investors derive utility from high re-

37. The statute provides the compensation may be

based on the asset value of the company or fund under management averaged over a specified period and increasing and decreasing proportionately with the investment performance of the company or fund ... in relation to the investment record of an appropriate index of securities prices or such other measure of investment performance as the Commission by rule, regulation, or order may specify.

$\$ 205$ Investment Advisers Act, 15 U.S.C. $\$ 80 \mathrm{~b}-5$ (1970). The details of developing an index may be found in 17 C.F.R. $\$ 275.205-1$ (1973). Calculation of an index's record is determined by summing the change in the level of the index with the cash distributions on securities composing the index. Dividends are treated as reinvested quarterly.

38. SEC Investment Advisers Act Release No. 315 (Apr. 6, 1972).

39. Id.

40. Id. See also Hyperion Fund, Inc., [1973 Transfer Binder] CCH FED. SEc. L. REP. If 79,315 (Arthur Lipper Growth Fund Index appropriate for a mutual fund which invests exclusively in shares of no-load mutual funds).

41. The SEC specifically rejected an index based on considerations of explicit risk as opposed to the implicit risk considerations in the adopted definition of the index. SEC Investment Advisers Act Release No. 315, at note 6 (Apr. 6, 1972).

42. See J. Lorie \& M. Hamirton, The Stock Market: Theories and Evidence 171 (1973) [hereinafter cited as LORIE \& Hamilton]; W. Sharpe, PortFolio TheORY and Capital Markets 27 (1970) [hereinafter cited as Sharpe].

One numerical surrogate for risk is the variance of the return of a portfolio. Use of the variance of a portfolio as the measure of risk is technically correct only where the returns of securities occur statistically according to a Gaussian "normal" distribution or where individuals behave as if maximizing a quadratic utility function. Samuelson, The Fundamental Approximation Theorem of Portfolio Analysis in Terms of Means, Variances, and Higher Moments, 37 Rev. Econ. Srud. 537 (1970). Returns, however, are distributed according to the Pareto-Levy function, not the well-behaved bell curve required by the theory. See Fama, The Behavior of Stock-Market Prices, 38 J. Bus. 34 (1965); Fama, Mandelbrot and the Stable Paretian Hypothesis, 36 J. Bus. $420^{\circ}$ (1963). And quadratic utility functions have anomalous properties-reduced ab- 
turns, but they also derive disutility from risk. Comparing the return of a fund portfolio with the return of the index portfolio without adjusting for differences in risk provides a misleading measure of fund performance. Even though a fund yields a high return, it may do so by subjecting an investor to an excessively high risk.

Capital market theory provides a means of ascertaining whether a portfolio's return adequately compensates a fund shareholder for the risk incurred. ${ }^{43}$ Basically the procedure involves comparing the fund with a hypothetical portfolio consisting of a risk-free asset and the market portfolio, i.e., the portfolio consisting of all securities held in proportion to their relative market value. ${ }^{44}$ The amount of the riskfree asset held in the hypothetical portfolio is varied to equate the risk of the fund's portfolio with the comparison portfolio. ${ }^{45}$ If the fund portfolio is riskier than the market portfolio, the market portfolio is levered until its risk is equated with the portfolio being compared.46

solute and relative risk taking as wealth increases and eventually negative utility of wealth. Borch, $A$ Note on Uncertainty and Indifference Curves, 36 REv. Econ. STUD. 1 (1969); Feldstein, Mean-Variance Analysis in the Theory of Liquidity Preference and Portfolio Selection, 36 Rev. ECON. Stud. 5 (1969).

Despite these theoretical infirmities evaluation of portfolios in two dimensionsmean and variance-is a significant advance from a one dimension measure of performance. Tobin, Comment on Borch and Feldstein, 36 REv. EcoN. STud. 13 (1969). Measurement of portfolio performance in only two dimensions might also not be too inaccurate where the underlying probability distribution is in a mathematically well defined sense "compact." See Samuelson, supra, at 542.

43. See Jensen, Risk, The Pricing of Capital Assets, and the Evaluation of Investment Portfolios, 42 J. Bus. 167 (1969).

44. At present there is no comprehensive market portfolio index, and various sub. stitutes have been used in its stead with reasonable results. Jensen, supra note 43 , used the Standard \& Poor's 500 Index, a market weighted index of 425 industrials, 25 railroads, and 50 utilities, LORIE \& HAMILTON, supra note 42, at 62. The New York Stock Exchange Composite Index is perhaps the most complete, being composed of all stocks listed on the Exchange. Like the Standard \& Poor's 500 Index, it is a value weighted index. It does, however, suffer from its brief span (since 1964). The ISR, supra note 17 , at 410 , suggested that the Standard \& Poor's 500 Index was the best available index. See generally Note, The Institutional Investor Disclosure Act: An Analysis of the Consumer Benefits, 83 YALE L.J. 1271, 1274-76 (1974).

45. A simple numerical example illustrates this process. Suppose the [risk, return] characteristics of $a$ fund are $[0.5,8.0]$ and that of the market and the riskfree asset are $[1.0,10.0]$ and $[0.0,5.0]$, respectively. Then a portfolio composed of the market and the risk-free asset may be constructed with characteristics [0.5, 7.5]. See generally Note, Regulating Risk-Taking by Mutual Funds, 82 YALE L.J. 1305, 1316-17 (1973); Note, supra note 44, at 1274-79. Comparing the return of this portfolio with that of the fund one can see that the fund has a positive return due to advice of 0.5 .

46. The unavailability of leverage at an interest rate equal to the risk-free rate creates a number of difficult theoretical problems about the conclusions of the capital asset pricing model. See generally M. JENSEN, Studies IN THE THEORY OF GAPITAL MARKETs 18-25 (1972); Jensen, Capital Markets: Theories and Evidence, 3 BELL J. Econ. McT. ScI. 357, 378 (1972).

There seems little doubt, however, that a risk adjusted performance measure is a significant improvement over a one dimensional test which looks to return alone; cf. Tobin, supra note 42. And most researchers in the field have assumed the possibility of leveraging at the risk-free rate when evaluating the performance of mutual funds. See, e.g., Jensen, supra note 43. 
The vertical distance above the "baseline" thus traced out is a measure of the fund manager's ability to "beat the market." 47

The SEC's failure to promulgate a risk-adjusted performance measure not only gives an illusory measure of a fund manager's performance, it also may induce excessive risk taking. Under $\$ 205$ a fund manager maximizes its performance fee if the fund's return exceeds that of the index; there is no reward for minimization of risk. ${ }^{48}$

The SEC realized that a market index adjusted for risk is an appropriate performance standard ${ }^{49}$ but it inexplicably failed to adopt the standard when it promulgated its regulations under $\$ 205 .{ }^{50}$ It should reconsider the adoption of such a standard, especially in view of the mounting evidence of the usefulness of accounting for risk as well as return.

Aside from the specification of the proper index, $\$ 205$ requires that rewards and penalties be symmetrical above or below the index. This performance structure limits fund company ability to bargain for larger penalties than rewards. Freedom to bargain for larger penalties might result in an advisory fee schedule which penalizes negative performance. This may more clearly reflect the shareholders' increasing disutility with performance below the standard. ${ }^{51}$

\section{Improving Disclosure}

The SEC rejected greater or modified disclosure as an effective way to control advisory fees; it recommended to Congress a judicial reasonableness test for these fees. ${ }^{52}$ There is some evidence, however, that shareholders can fend for themselves if they are aware of performance. ${ }^{53}$ The SEC should, therefore, in accordance with the policy of

47. Jensen, supra note 43, at 193. See also LoRIE \& HAMiLton, supra note 42, at 241-44; SHARPE, supra note 42 , at 83 .

48. Simulation experiments confirm the theoretical predictions that risk taking is increased by performance fees structured along $\S 205$ lines. See F. Modigliani \& G. Pogue, A Study of Market Line Investment Performance Fees, April 1973, at 6-10 (working paper, Alfred P. Sloan School of Management, M.I.T.) (also on file with the Yale Law Journal). The reduction of excessive risk taking was one of the goals of $\S 205$. S. REP. No. 184, supra note 16 , at 45 .

49. ISR, supra note 17 , at $367,400-10$.

50. SEC Investment Advisers Act Release No. 315, at 6 (Apr. 6, 1972).

51. A related problem involves the relative magnitude of the base fee. The base fee is usually calculated as a percentage of assets, and the worst possible penalty under the performance arrangement will not produce a negative total fee. See, e.g., ISR, supra note 17, at 256. SEC Investment Company Act Release No. 7130, at s (Apr. 17, 1972), reports that 21 companies had a minimum fee of zero (never negative), but the remaining sample of 103 companies always received a residual fee irrespective of performance.

52. PPI, supra note 5 , at $147,148$.

53. See, e.g., ForBes, Aug. 15, 1973, at 67 (investors have committed more money to funds with superior performance records). 
the Investment Company $\mathrm{Act}^{54}$ update disclosure requirements in order to mitigate the adverse effects of less than adequate information concerning investment companies.

\section{A. What to Disclose}

At present, disclosure requirements under the Securities and Investment Company Acts do not require any disclosure of performance. ${ }^{.5}$ The limited requirements on the form of "performance" claims made in sales literature ${ }^{\tilde{6} \theta}$ are much less restrictive than the regulations governing construction of performance indexes for $\S 205$ of the Investment Advisers Act. Performance of the fund's shares may be illustrated in sales literature by treating dividends as distributed, and capital gains as reinvested. ${ }^{57}$ There is no substantive regulation of performance claims other than the requirement of a few caveats which point to differences between the index and the fund's portfolio. ${ }^{58}$ The SEC appears to view the main purpose of disclosure required in investment company prospectuses as identification of specific instances where an advisory company may be self-dealing. ${ }^{59}$ No attempt is made to give the investor the information necessary to enable him to determine the value of the payments which are made to the advisory company. Such information is essential, since the management fee is probably the largest noninvestment expenditure made by the fund, and its magnitude is negotiated in a transaction fraught with conflict of interest. Information about performance and the advisory fee should

54. The legislative statement of policy may be found in the Investment Company Act, 15 U.S.C. $\$ 80 \mathrm{a}-1(\mathrm{~b})(1)(1970)$. See also ISR, supra note 17, at xifi, xix.

55. Because the open end mutual funds engage in continuous distribution, they must comply continuously with 1933 Act registration requirements. The prospectus requirements may be found in $\$ 10$ of the Securities Act and 17 C.F.R. $\$ 271.150$ (1973). The contents of the filed registration statement are prescribed by $\$ 24$ of the Investment Company Act, 15 U.S.C. $\$ 80 \mathrm{a}-24$ (1970). The SEC presently requires updating of performance claims made in sales literature. See SEC Investment Company Act Release No. 2621 (Oct. 31, 1957).

56. The requirements are set out in SEC Investment Company Act Release No. 2621 (Oct. 31, 1957).

57. Compare SEC Investment Company Act Release No. 2621 (Oct. 31, 1957), with 17 C.F.R. \$ 275.205-1 (1973) (requiring dividends to be treated as reinvested quarterly for purposes of $\$ 205$ ). Since the division of total return between dividends and capital gains may be different for a fund than for the index, failure to treat dividends as reinvested may overvalue the performance of a fund with little dividend return.

58. SEC Investment Company Act Release No. 2621, I (n) (Oct. 31, 1957).

59. See, e.g., the items required by Form N-8B-1 (Registration Statement of Management Investment Company): items 13 (Persons in Control Relationship with Registrant), 23 (Business and Other Connections of Investment Advisers and Their Management), and 25 (Remuneration of Certain Affiliated Persons); and the items required by Form N-1R (Annual Report of Management Investment Company): items 1.12 (Remuneration of Directors, Officers and Members of Advisory Board), 1.13 (Remuneration of Certain Other Affiliated Persons) and 1.20 (Business and Other Connections of Management and of Investment Adviser). [1969. Transfer Binder] CCH FED. SEC. L. REP. \& $51,293,51,963$. 
fall within prospectus definitions of material information since it would influence the decision of a rational investor to purchase the security. ${ }^{60}$

Capital market theory provides some guidance about the information necessary to evaluate a fund and its management. The risk and return of the fund are, of course, crucial, as is the return on the comparison standard-the market index adjusted by combining the riskfree asset to equal the risk of the fund portfolio. This information enables an investor to distinguish superior performance from luck. The risk-adjusted measure of performance should be part of the synthesis of the data required to be disclosed. ${ }^{61}$

Performance as well should be measured over a suitable period of time. There are two conflicting policies in choosing a period over which to measure performance. First, the period should be sufficiently long that random influences are minimized. Second, the period should be short enough to be responsive to changes in the performance of the fund due to new advisory capabilities. To reconcile these conflicting goals, disclosure of performance both for long and short periods could be required.

The SEC should also consider disclosure of the return on the fund less the risk-free return per unit risk. This synthesis of data would provide the shareholder an easy method of comparing the possible return at different risk levels. ${ }^{62}$ By allocating part of his or her funds to a risk-free asset or by borrowing in combination with purchasing the fund, the investor could assemble a portfolio with risk and return which most closely matched his or her preferences. ${ }^{03}$

\section{B. Timing for Disclosure}

A key element of any disclosure scheme is timing: The pertinent information must reach an investor early in the decisionmaking proc-

60. 17 C.F.R. $\$ 230.405(1)(1973)$.

61. Synthesization has been required for earnings per share figures, SEC Securities Act Release No. 4910 (June 18, 1968). The general trend is toward data synthesis which would permit of comparisons among companies. SEC Securities Act Release No. 5342 (Dec. 18, 1972).

62. The possibility that an unsophisticated investor might consider this figure a measure of absolute superiority suggests the inclusion of caveats alerting the investor of the necessity to consider his or her own risk preferences.

63. See LoRIE \& HAMILTON, supra note 42, at 236; ShaRrE, supra note 42, at 154.60. Sharpe points out two possible measures: return minus risk-free return divided by variability (total variance), or return minus risk-free return divided by volatility (market covariance).

Sharpe points out that the variability measure is appropriate when the portfolio represents an investor's total investment. SHARPE at 154. This Note favors total variance measures. Sophisticated investors who view the fund as only a part of their total diversified investment are not the persons primarily in need of protection from misleading performance measures which do not take account of risk. 
ess in order for such information to affect the decision to buy or sell. The inertia of prior deliberations might obscure the usefulness of information received later. In order to guarantee the receipt of information early in the decisionmaking process, the Securities Act mandates delivery of a prospectus which meets the requirements of $\S 10$ once a written offer to sell is made. ${ }^{64}$ Mutual funds argue that the Securities Act should not apply to them. ${ }^{05}$ They point to their relative safety and to the fact that they compete with other modes of investment-life insurance, bank accounts-which are not subject to the Securities Act. ${ }^{66}$ The SEC has responded to these arguments by exempting certain advertisements from the definition of offer to sellor and by permitting funds to use a summary prospectus. ${ }^{68}$ These changes permit brief descriptions of the activities of a fund to appear in advertisements intended to reach the general public. Previously such advertisements had been permitted to refer only to the statutory prospectus for such information. ${ }^{69}$ The new summary prospectus may be distributed with other sales literature, but it does not satisfy the prospectus delivery requirements. ${ }^{70}$ The new summary prospectus must admonish potential buyers to examine the full prospectus before buying, and the full prospectus must be readily available. ${ }^{71}$

The availability of the full prospectus does not, however, mean that the content of the summary prospectus or the advertisements describing the fund are unimportant. Disclosure of performance should be made whenever performance claims are asserted, as, for example, when a company chooses to display its record of performance in a general advertisement. ${ }^{72}$ The SEC should also mandate use of the risk-

64. Securities Act of $1933 \$ 5(\mathrm{~b})(\mathrm{I}), 15$ U.S.C. $\$ 772$ (1970).

65. Romanski, The Role of Advertising on the Mutual Fund Industry, 13 B.C. INd. \& Com. L. Rev. 959, 1001 (1972).

66. Id. at 1001 n. 227.

67. Rule 135. , 17 C.F.R. \$230.135a (1973) (generic advertising). An expansion of the "tombstone" ad is Rule 134(a)(3) iii, 17 C.F.R. $\$ 230.134$ (a)(3)(iii) (1973). Further expansion is being considered, SEC Securities Act Release No. 5357 (Jan. 17, 1973).

68. SEC Sccurities Act Release No. 5248 (May 9, 1972); Rule 434A, [1971-72 Transfer Binder] CCH Fed. SEc. L. REI. 78,760. This rule modified the previous exclusion of in. vestment companies from the generally permitted use of such ads. See 17 C.F.R. $\$ 230.434$ (a (1973); Sccurities Act of $1939 \$ 10(\mathrm{~b}), 15$ U.S.C. $\$ 77 \mathrm{j}(\mathrm{b})$ (1970).

69. For a discussion of the restrictiveness of these ads, see $R$. JenNings \& H. MARsh, SECURITIES REguLATION 1570 n.4 (1972).

70. Securities Act of $1933 \$ 5(\mathrm{~b})(2), 15$ U.S.C. $\$ 77 \mathrm{e}(\mathrm{b})(2)(1970)$, requires delivery

of a statutory prospectus upon delivery of the securities.
71. SEC Securities Act Release No. 5248 (May 9, 1972).

72. Where no performance is asserted by the company, a general advertisement does not seem to be a suitable point at which greater performance disclosure should be required. Such ads educate people by making them aware of investment opportunities in mutual funds. The SEC should allow a "tombstone" ad broad enough to arouse interest, but it should not impose requirements of disclosure so expensive as to make the broad dissemination of the ad impossible. For the contrary position, sec Romanski, supra note 65 , at 1016. 
adjusted measure of performance. ${ }^{73}$ This would provide an accurate and uniform measure of an investment manager's ability.

As more investors base their purchases on an accurate measure of performance, funds which spend an excess amount of money on nonproductive research and trading will be penalized by net redemptions of utility-maximizing shareholders. By contrast, funds which minimize costs should, in the long run, outperform the market and attract the capital of informed investors. This competition should lead to a reduction in the size of advisory fees as a percentage of total net assets. Although the result can be tested empirically only after the regulation is tried, enhancing competition through dissemination of accurate performance measures should be preferred to direct methods of control which are uncertain both as to method and results. ${ }^{\text {Tt }}$

\section{Enhancing Shareholder Control}

The 1970 Investment Company Act Amendments rejected as a regulatory approach not only disclosure, but also the pre-1970 strategy of requiring investment company structures which permit shareholder participation in the fund's decisionmaking ${ }^{75}$ and which assure that some members of the board of directors will have no direct interest in the advisory company. ${ }^{76}$

With respect to shareholder voting control the SEC found that the right of shareholders to approve an advisory contract "may well have served to discourage advisers from charging fees at rates higher than the traditional 0.50 rate." 77 The SEC concluded, however, that because the rate failed to fall from the industrywide one half of one percent of company assets, the shareholders were unable to demand anything better through their power of approval of the advisory contract. ${ }^{78}$

An equally plausible explanation is that shareholders do not have the opportunity to approve advisory contracts often enough to exert

73. Full disclosure of performance might also be required in certain circumstances when an investor and a fund salesperson engage in oral discussion of mutual fund securities. Although the Securities Act does not regulate oral solicitations once a registration statement has become effective, see Lobell, Revision of the Securities Act, 48 Colum. L. REv. 313, 322-24 (1948), regulation of oral solicitation after registration might be an appropriate subject of self-regulation by the exchanges or the National Association of Security Dealers (NASD). It would be similar to suitability rules. Set generally $\mathrm{R}$. JENNINGS \& H. MARSH, supra note 69 , at $810-11$.

74. See note 53 supra for evidence that shareholders do purchase those funds which perform best. See also Note, supra note 44 , at 1273 .

75. See pp. 1476-77 supra for examples of pre-1970 structural guarantees.

76. See note 12 supra.

77. PPI, supra note 5, at 128.

78. Id. at 130. 
control. The Investment Company Act requires shareholder approval of an advisory contract only once. ${ }^{79}$ Long after this original approval, growth of the fund may make the one half of one percent rate unreasonable. Shareholders have no opportunity to express disapproval ${ }^{80}$ except as such disapproval could be expressed through election of directors. ${ }^{81}$

This barrier to shareholder control could be overcome by a statutory amendment requiring that shareholders vote annually on the investment advisory contract. Even without such an amendment the SEC could probably exert some pressure for annual approval of the contract through its power to bring an action under $\S 36(\mathrm{~b})$ of the Investment Company Act. Section 36(b)(2) provides that a court should consider shareholder ratification of a contract in determining whether directors have breached their fiduciary duties.

One objection to frequent shareholder approval of contracts is that it may produce changes which are not desired by minority shareholders. The desire that past policies be continued is important in most corporations since a shareholder is traditionally believed to have an interest in the joint venture to which he or she has committed capital. ${ }^{82}$ In fund companies the strength of this interest is weakened by the right of redemption at a highly accurate determination of fair market value of net assets per share. ${ }^{33}$ Redemption, in this situation, may be viewed as a continuous appraisal right. ${ }^{84}$

The SEC makes a second argument against enhanced shareholder

79. The Investment Company Act $\$ 15(\mathrm{a}), 15$ U.S.C. $\$ 80 \mathrm{a}-15(\mathrm{a})$ (1970), provides that all advisory contracts must be approved by a majority of the outstanding voting securities. Renewals, which are required annually, may be made either by the board of directors or the stockholders, id. $80 \mathrm{a}-15$ (c). See note 81 infra for an example of a tenacious postponement of shareholder ratification.

80. The Commission concedes that the one half of one percent rate at which most advisory fees are calculated is reasonable for smaller funds. PPI, supra note 5, at 148 \&. 149 .

81. See Investment Company Act $\$ 16,15$ U.S.C. $\$ 80 \mathrm{a}-16$ (1970). Only substantial changes in advisory contracts must be submitted to the shareholders for approval. See, e.g., Acampora v. Birkland, 220 F. Supp. 527 (D. Colo. 1963) (contract in effect for twenty years without shareholder ratification).

82. In fact, at common law such interest was so dominant that sales of substantially all the assets of a corporation were not valid unless such sales had unanimous stockholder approval. See, e.g., Butler v. New Keystone Copper Co., 10 Del. Ch. 37I, 377, 93 A. 380, 383 (1915). See also Annot., 79 A.L.R. 624 (1932). Appraisal was a statutory protection provided to replace the common law absolute right when statutes overruled the common law prohibition on such sales. In re Fulton, 257 N.Y. 487, 178 N.E. 776 (1931). See note 96 infra for a contrary view of this appraisal right.

83. The requirements as to value determination are set out in 17 C.F.R. $\$ 270.22 \mathrm{c}-1$ (1973).

84. The redemption right is not quite as attractive in the case of so-called "load funds." The original sales load charge is somewhat higher than on sales of other securitics. Computed as a percentage of total share cost, commission load charges range from seven to nine percent. PPI, supra note 5 , at 52.54 . 
control. ${ }^{85}$ The argument is that shareholder rejection of an advisory contract would leave a fund with no adviser. This might not be an intolerable state for a short period of time. A well diversified fund will attain a certain level of performance without any research guidance. But assuming that a fund must have an adviser at all times, directors need not wait until expiration of the old advisory contract to seek shareholder approval of a new one. If renewal approval is sought well before the expiration date of the old contract, the directors should be able to find a substitute adviser if necessary. Directors might also provide in proxy solicitation for approval of an interim contract in the event that the long-term contract is unacceptable to the shareholders. Another alternative would be internal management during an interim period without a contract.

In view of the profitability of managing a fund, it seems unlikely that a fund would go very long without a contract before competitors submit bids on managing the fund. ${ }^{86}$ By restoring to shareholders their economic bargaining power-termination of the advisory contract-and by requiring directors to entertain competitive bids for the position of investment adviser, contract negotiation might more truly resemble arm's length bargaining. Such a result would be consistent with the lower advisory fees for accounts of a similar size of corporate, individual and other institutional investors. ${ }^{87}$

These solutions are much more attractive than the limited shareholder input registered through election of directors. ${ }^{88}$ Even directors not affiliated with the fund's advisers may be persuaded by the advisory company personnel to adopt a view similar to that of the advisory company. Moreover, there is no reason for shareholders to desire a division of responsibility for the management of the company ${ }^{80}$ between two sets of persons-the advisory company and the fund's own staff. Such division of responsibility would generate redundant expenses and deprive the shareholders of the advisory company's expertise within the fund.90 The noninterested directors would be just

85. Id. at 129 .

86. Id. at 124 , shows an attractive investment of a range of 13 percent to 60 percent profit margin and in absolute terms up to $\$ 10$ million profit per year.

87: See ISR, supra note 17 , at 23 , 210. See also id. at xiv, where competitive pressures were cited as a reason for not necding to extend $\$ 205$ to other institutional investors.

88. The SEC itself takes the position that election of directors has little effect on the advisory contract. PPI, supra note 5 , at 130 . Interested person is defined in $\$ 2$ (c)(19) of the Investment Company Act, 15 U.S.C. $\$ 80 \mathrm{a}-2$ (c)(19) (1970). See also id. $\$ 80 \mathrm{a}-2(\mathrm{a})(3)$ (1970) (definition of "affiliated" persons).

89. Cf. Lobell, supra note 6, at 206.

90. Interesting examples of duplication and confusion which occur in investment companies' expenses may be found at PPI, supra note 5, at 91 . 
other agents for which a method of assuring responsibility to the shareholders would have to be developed. ${ }^{91}$

The SEC also raised doubts about the wisdom of shareholder control over advisory contracts because of the imperfections of the proxy system of voting. ${ }^{22}$ These imperfections may, however, be partially eliminated. First, under present law, the SEC could require that the proxies explicitly notify shareholders of their opportunity to express dissatisfaction with the advisory contract and alert them to the importance of literature available to them ${ }^{03}$ which includes the disclosure items. ${ }^{94}$

Second, Congress should amend the statute ${ }^{95}$ to provide that the shareholders be given the opportunity on all contract votes to express three different choices with regard to entering a new contract with the advisory company: (l) that the directors should accept the contract as it is written; (2) that they should renegotiate the contract; and (3) that they should seek a new adviser as if no special relationship existed with the old adviser.

These last two mandates to the directors would present a conflict of interest for the interested members of the board. Thus only noninterested directors should participate in renegotiation when shareholders make the second choice. The last choice is a decision to sever special relations with the advisory company. If the shareholders so vote, the interested directors should be required to resign, noninterested directors should nominate successors for those resigning, and

91. The development of such control is consistent with pre-1970 regulation which looked to full sharcholder equity participation to control advisory fees. See Investment Company .Act $\$ 1$ (b)(2), I5 U.S.C. $\$ 80 \mathrm{a}-1$ (b)(2) (1970).

Those readers skeptical of shareholder ability to control corporate decisions should keep in mind that the decision discussed in the text is narrowly circumscribed to the issue of satisfaction with the performance of the fund and hence the value of the advisory services. Given proper information and a standardized computation, dissatisfaction on an isste this crucial and requiring no more judgment than the original decision to invest in a fund may be expressed effectively.

92. PPI, supra note 5 , at 128 .

93. This could be required as a regulation similar to I7 C.F.R. $\$ 270.20 \mathrm{a}-20$ (1973) which requires that certain information regarding the investment adviser and the advisory contract be furnished as part of the proxy material. Another suitable vehicle of disclosure is the annual report which must be sent to shareholders prior to the solicitation of proxies by rules under $\$ 14$ of the Securities Exchange Act, 15 U.S.C. $\$ 78 \mathrm{n}(1970)$ and $\$ 20$ of the Investment Company Act, 15 U.S.C. $\$ 80 \mathrm{a}-20$ (1970). Its form is prescribed by the SEC. See Form N-IR, [1973 Transfer Binder] CCH FED. SEC. L. RLP. I 51,961 .

94. The terms of the advisory contract should be disclosed as presently required. 17 C.F.R. $\$ 270.20 \mathrm{a} \cdot 2$ (1973).

95. The actual choices suggested in the text could fit well into regulations under $\$ 14$ of the Securities Exchange Act. See, e.g., 17 C.F.R. 240.14a(b) (1973) (providing for an opportunity to express disapproval on a management proposal); 17 C.F.R. $\$ 240.14 a-8$ (1973) (providing an opportunity for shareholder proposals). The provisions for resignation of directors and renegotiation of contracts seem to be outside the scope of $\S 14$ or $\$ 20$ of the Investment Company Act, 15 U.S.C. $\S \S 80 \mathrm{a}-14,-20$ (1970). 
the new board should seek an adviser. ${ }^{96}$ Since the noninterested directors will be operating under a specific mandate of the shareholders, their actions will be under the direct control of shareholders who possess an economic interest in the fund. ${ }^{97}$

\section{Conclusion}

The 1970 Amendments to the Investment Company Act and the Investment Advisers Act departed from past approaches to regulation of fees paid to investment advisers of mutual funds through shareholder control and complete disclosure. The amendments regulate fees by allowing the courts to test on an ad hoc basis their reasonableness at the behest of shareholders and by establishing a performance fee structure which was thought to be substantially correct. The courts should not be used to regulate advisory company fees because of the nature of the judicial function. Furthermore, the substantive regulation regarding performance fee structure, even if properly implemented by the SEG, does not control the dynamic process of setting fees and is too restrictive to allow rational bargaining over fee structure.

The SEC should act under present law to improve disclosure and to make shareholder control more meaningful. Legislation is suggested which would give shareholders an opportunity to exert meaningful direct control over fees paid to advisory companies. This Note's suggestions should promote a fee structure similar to one which would be determined by arm's length bargaining between a fund and advisory company without encountering the problems of the 1970 Amendments.

96. At this point the old adviser should not be foreclosed from being the choice of the board, but should the board choose this adviser and a new contract be rejected by the shareholders, the board should exclude the old adviser from further consideration. It seems essential to any meaningful shareholder control that the ad. visory group not be allowed to continually submit proposal after proposal to the amorphous shareholder group of a mutual fund, which group might yield to the sheer persistence and futility of resistance.

97. A new adviser once found should be allowed to nominate successor directors to run against a noninterested slate to give the shareholders an opportunity to place control in one person. This particular suggestion does not conflict in any way with proposals such as S.4071, 92d Cong., 2d Sess. (1972), which would require a noninterested board for three years following the sale of control of the advisory company. Such proposals are principally concerned with the problems associated with voluntary sales of advisory office. See Sterrett, supra note 35, at 250. 